Book Review

(C) Journal of International Students

Volume 10, Issue 4 (2020), pp. 1110-1113

$\underline{\mathrm{O} J E D}$

ISSN: 2162-3104 (Print), 2166-3750 (Online)

Doi: $10.32674 /$ jis.v10i4.2348

ojed.org/jis

\title{
Student and Graduate Mobility in Armenia
}

\author{
D. Cairns \& M. Sargsyan, 2019. Palgrave Macmillan: ISBN 978-3-030-19613-4
}

Reviewed by Natalie Cruz, Old Dominion University, USA

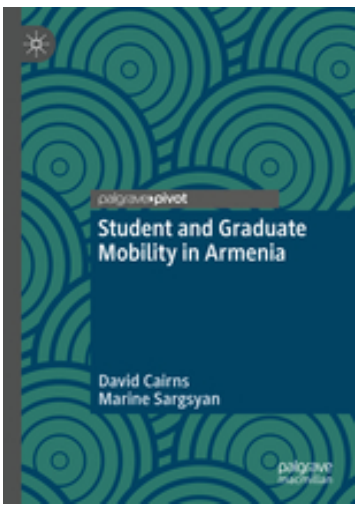

The book Student and Graduate Mobility in Armenia by David Cairns and Marine Sargsyan makes several important contributions to the rapidly proliferating global student mobility research field. Cairns and Sargsyan focus on the individualized journeys of mobile Armenians through lesser researched perspectives, like the spatial context, postgraduate lens, and other theoretical frameworks. Readers may be quick to assume this book is not widely applicable because of its specialized focus on Armenia, a small eastern European country that does not send or receive large numbers of students. That would be a mistake, however, as this book undoubtedly provides its readers with fresh perspectives that can be applied in a variety of international higher education contexts. Researchers and practitioners worldwide-including those in education, sociology, political science, psychology, career development, and international relations - who desire to understand the employment pathways and internal and external mobility motivations of international students throughout the academic life cycle will find this book to be particularly insightful and valuable.

Cairns and Sargsyan examine highly skilled graduate and student mobility with three unique approaches: (a) the rarely studied spatial and geographical context of Armenia, (b) the theoretical lens of reflexive mobility, and (c) a focus on postgraduate mobility. Any one of these approaches would be a novel take on the current mobility literature, but the combination of these three make their work particularly significant. Their book is informed by 51 individual interviews as part of a qualitative research study with Armenian people who were living or studying abroad or had been mobile at some point in their recent adult life. 
The authors make a strong case for Armenia as the research context because mobility in Armenia is severely underresearched, is outside the European Union, and highlights voices and trends from underdeveloped areas. Researchers working in nonAnglophone, medium income, or postcolonial countries may find the results from their study and this book particularly helpful.

The authors also introduce a theoretical lens they describe as reflexive mobility, which is "the idea that decision-making can be conceptualized as a reflective process" (p. 13). The book demonstrates the participants' use of reflexive thinking as they make their mobility choices based on internal and external reasons. The authors also argue that reflexive mobility individualizes the decisions of participants, and pushes back against the notion that the impetus for mobility is primarily economically motivated. In particular, Cairns and Sargsyan problematize much quantitative research that has been conducted in the past to understand the phenomenon of global student mobility. In their view, large scale, survey, or secondary data studies "describe rather than explain mobility, using secondary statistics to chart recent trends and administrative data to assess the impact of stays abroad upon their completion, with fieldwork involving conveniently located research subjects such as incoming student migrants and exchange visitors" (p. 14). Their book attempts to explain, not simply describe, mobility by highlighting students and graduates from Armenia through rich personal decisions and pathways shaped by individual experiences.

Student and Graduate Mobility in Armenia is a quick read and accomplishes a great deal in less than 100 pages. The first two chapters set up the context and theoretical framework of the book; Chapters 3, 4, and 5 highlight the main findings of the study; and Chapter 6 offers a conclusion and follow-up on developments from a recent political revolution.

Chapter 1, "Armenia in Context," explains their reasons for focusing on Armenia, problematizes prior mobility studies and theoretical approaches, and discusses the research questions and methodology. Most of the interviews with the 51 participants were conducted in Yerevan, Armenia, between July and September 2018.

Chapter 2, "Reflexive Mobility," explains the theoretical framework for the book. Inspired by the work of sociologist Margaret Archer, internal and external dialogue is hypothesized as critically important for participants' mobility decisions. The authors argue that agency and social networks are vital for the prospect of outward mobility. Additionally, they suggest that globally mobile individuals plan their outward ventures with a long-term view, often carefully considering how their decision will impact their life and help achieve their goals. This chapter also introduces a few of the participants' perspectives and uses extended examples from two people to demonstrate how mobility decisions can be complex, ambiguous, and much different than they appear to outsiders.

Chapter 3, "Spatial Pathways to Work," outlines and explains the three most common pathways where mobile Armenians choose to work and enroll in university education: Russia, the United States, and the European Union. One provocative suggestion the authors make based on their research and other studies is that students who studied in the United States do not seem to increase their employability or intercultural skills like those that study through the Erasmus program. Highlighted 
participants explain the main issues in the Armenian workplace that contribute to people leaving, which includes challenges around power, money, and patriarchy.

Chapter 4, "Working Inside and Outside Armenia," discusses the type of employment opportunities and challenges that the research participants have in Armenia and other countries. This chapter raises the important consideration that educated Armenians with academic capital have higher expectations and often take longer to find gainful employment. Many of the employment issues in the Armenian context are quite universal, but corruption is one major challenge that is perhaps unique to the post-Soviet world. For example, one interviewee who was a recent graduate of Yerevan State University described how Armenians often had to pay large fees to an agency to obtain a mediocre-paying job. She shared: "I see no sense or point in paying 3000 USD for a position in a school where the salary is about 140 150 USD and besides, I didn't study and pay fees for six years to then pay for an appointment. People get positions through connections, and they may not have good qualifications, but connections and the bribe come first." Rich participant examples such as these are woven throughout the book.

Chapter 5, "Mobility in Transition," discusses the Velvet Revolution and highlights participants' thoughts and feelings about how the recent political microrevolution impacts their plans and thought processes about mobility. Chapter 6, "Postscript," follows up several months after the data collection, the occurrence of the Velvet Revolution, and the installment of a new president. The final chapter offers three conclusions from the analysis of 51 interviews: (a) Armenian mobility overwhelmingly follows three predictable pathways of the United States, Russia, and the European Union; (b) the ability to be mobile is often important to find gainful employment; and (c) Armenians face many difficulties throughout their spatial circulation endeavors.

The participants' voices are the lynchpin of the book, and the authors highlight, not diminish, the unique elements of each person's situation. Participant examples and quotes are teeming with examples of agency through mobility, and they challenge us to consider every student's mobility journey as a story of grit, determination, and purpose. As opposed to viewing mobile Armenians as primarily reacting to the negative circumstances in their own country, or pulled toward more viable situations in other countries, they explain the complicated reasons that people may choose to go abroad (or not) in spite of their potential options. In one particular example, we hear from one participant about their choice to stay in Armenia: "I applied for a vacancy, passed the exams, went through all the stages, and got the position. I work now at the same place, having achieved a lot in regard to my career in banking. [...] At one stage of my career, I was considering and thinking about working or studying abroad, more specifically in the US, but I found myself staying in Armenia" (p. 53). These types of stories where students forego economic potential to stay in their home country are not often shared in student mobility research.

In a crowded field of undertheorized journal articles, books, and practitioner pontifications about student mobility, Student and Graduate Mobility in Armenia pushes the field of global student - or more accurately postgraduate - mobility forward. The work of Cairns and Sargsyan should encourage other researchers and 
readers of this book to expand the field by highlighting postgraduates' experiences from emerging countries and contexts.

NATALIE CRUZ is a current $\mathrm{PhD}$ candidate studying higher education at Old Dominion University. Her research is focused on changing modes of global student mobility, the importance of entrepreneurialism for international education leaders, and other transnational education issues. E-mail: ncruz004@,odu.edu 